\section{ARTERIO-SCLLROSIS IN COAL MINERS.}

BY

D. LLLIOT DICKSON, M.D., F.R.C.S.ED., LOCHGELLY, FIFE;

AND

W. ARNOTT DICKSON, M.D., M.R.C.P.Ev., F.R.C.S.ED., D.P.H. GLOUCESTE?

Artuocas it is now generally held that the contitions connected with a miner's occupation, apart from its special risks, are as favourable to health as those of other manual workers, it should be noted that after the age of 55 coal miner's in the aggregate die off more rapidly than other occupied males, while between the ages of 25 and 55 tho death rate is lower.

TABLE I.-Occupational Nortality at Different Age Groups.

(From the Registrar-General's Returns, 1921-23, p. 8.)

\begin{tabular}{|c|c|c|c|c|c|c|c|c|}
\hline \multicolumn{4}{|c|}{ Age Gronps : } & \multirow{2}{*}{$\frac{25-}{100}$} & \multirow{2}{*}{$\frac{35-}{100}$} & \multirow{2}{*}{$\frac{45-}{100}$} & \multirow{2}{*}{$\frac{55-}{100}$} & \multirow{2}{*}{$\frac{65 \text { and up }}{100}$} \\
\hline Occupi & ales & $\ldots$ & $\ldots$ & & & & & \\
\hline Miners & ... & $\ldots$ & $\ldots$ & 91 & 88 & 84 & 105 & 130 \\
\hline
\end{tabular}

The Registrar-General's return for 1921-23 sars: "Analysis of the causes throws very little light on the reason for the relative increase which occurs in the mortality of miners."

Twenty years ago, while associated in a large practice in Fife, we noted with surprise many cases of arterial thickening among coal miners, even in quite young men. This discovery suggested the srstematic examination of a considerable number of miners. In all, 500 men werc examined. They were taken consecutively, as they came into our surgeries, but no one was included who complained of any symptoms referable to his circulatory system. As a matter of fact, many of them were literally taken in off the street for the purpose of this inquiry.

Fven at this late date it scems desirable to publish the results, as no work on similar lines has been undertaken in the interval, and no light has yet been supplied to the Registrar-General. It is possible that our results contribute one explanation of the anomaly to which he refers.

Scheme of Examinations.

The examinations were carried out, as a rule, in the evening between 6 and 7 o'clock; a. few were done in the morning between 9 and 10. All the men had been off work for at least four hours, and no man was examined immediately after a meal. The routine procedure was as follows. While the man was standing his pulse rate was counted and the condition of the wall of the radial artery was noted. He was then directed to lie down, when particulars of his habits as to alcohol and tobacco, and the conditions of his work, were obtained, and his medical history was inquired into. The chest wall was then exposed and the apex beat located, the carcliac dullness mapped out, and the different areas auscultated. 'The pulse was again counted. The patient was then seated on a chair, the left arm bared to the shoulder, and the blood pressure taken (a mercurial manometer and a $12 \mathrm{~cm}$. armlet wcre used throughout). In a limited number of cases a blood count was done and a haemoglobin estimation made. The majority of the men examined were of the phlegmatic type, so that little effort was required to secure the psychical repose which is so desirable in taking blood pressure readings.

\section{Results.}

It may at once be stated that the outstanding feature of this inquiry has been the discovery of an extraordinary prevalence among miners of arterial thickening, as evidenced in the radial artery, a prevalence hitherto undescribed, and apparently unsuspected. Of the 500 miners examined only 44 (9 per cent.) had arteries which could not be palpated. The remaining 456 ( 91 per cent.) had definitely palpable arteries.
There is, of course, no difficulty in determining when an artery is thickened. It is as easy to feel a thickened artery as it is to feel a rubber tube; the difficulty arises when one tries to convey an idea of the amount of thickening present. For purposes of tabulation an attempt has been made to classify these arteries under the following definitions.

A. Not l'alpable.-An artery the wall of which cannot he detected by the pulp of the examining finger.

B. Thirl.-An artery whose wall can be flattened by the finger, but can then be easily felt in its entire breadth, like a piece of thick tape.

C. Very Thick.-An artery whose wall rolls readily under the finger, like a piece of rubber. tubing, and can be flattence only with difficulty. It is nearly always tortuous.

D. Atheromatous.-This is the "ipecacuanha root" artery of the late Dr. G. A. Gibson, showing marked calcareous degeneration.

No attempt was made to measure the actual size of the arteries, and the description applies solely to thickness, as gauged by palpation.

The total number of arteries classified under each group is as follows: $\mathbf{A}, 44 ; \mathbf{B}, 318 ; \mathbf{C}, 136 ; \mathbf{D}, 2$. These figures convey an idea of the general type of thickening met with. Since the age factor enters so largely into the question of arterial changes, we have arranged the 500 cases according to age, as shown in Table II.

TABLE II.-Arteries Arranged in Age Groups; shouing Actual Numbers and Percentages.

\begin{tabular}{|c|c|c|c|c|c|c|c|c|c|c|c|}
\hline \multirow{2}{*}{\multicolumn{3}{|c|}{$\begin{array}{l}\text { Age in } \\
\text { Years. }\end{array}$}} & \multicolumn{2}{|c|}{ A. } & \multicolumn{2}{|c|}{ B. } & \multicolumn{2}{|c|}{ C. } & \multicolumn{2}{|c|}{ D. } & \multirow{2}{*}{$\begin{array}{c}\text { Total } \\
\text { No. }\end{array}$} \\
\hline & & & No. & $\begin{array}{c}\text { Per } \\
\text { cent. }\end{array}$ & No. & $\begin{array}{c}\text { Per } \\
\text { cent. }\end{array}$ & No. & $\begin{array}{c}\text { Per } \\
\text { cent. }\end{array}$ & No. & $\begin{array}{c}\text { Per } \\
\text { cent. }\end{array}$ & \\
\hline 20 and & inder & $\ldots$ & 16 & 13.8 & 94 & 80.9 & 6 & 5.1 & 0 & - & 116 \\
\hline $21-30$ & $\ldots$ & $\ldots$ & 17 & 9.4 & 128 & 71.0 & 35 & 19.4 & 0 & - & 180 \\
\hline $31-40$ & $\ldots$ & $\ldots$ & 11 & 10.1 & 61 & 54.7 & 39 & 35.0 & 0 & - & 111 \\
\hline 4150 & $\ldots$ & $\ldots$ & 0 & - & 25 & 41.3 & 36 & 58.6 & 0 & - & 61 \\
\hline Over 50 & $\ldots$ & $\ldots$ & 0 & - & 10 & 31.2 & 20 & 62.4 & 2 & 6.2 & 32 \\
\hline Tot & & $\ldots$ & 44 & & 318 & & 136 & & 2 & & 500 \\
\hline
\end{tabular}

The salient feature of these figures is the very great frequency of arterial thickening in rouths of 20 rears of age and under. While the proportion of normal (A) arteries in that particular group is greater, as would be expected, than in any other, yet to have so preponderating a proportion of thickened radials (100 ont of 116) in healthy boys of 14 to 20 years is exceedingly striking. After the age of 40 none of the men had arteries which were not palpable. With increase of age there is a gradual and almost uninterrupted progression in the thickening of the arteries.

\section{Pathology of Arterial Thickening.}

Arterial thickening as evidenced in the radial artery may be due to one of three different conditions: arteriosclerosis, atheroma, or hypertonus. Arterio-sclerosis may be defined in general terms as a diffuse organic thickening of the arterial wall perceptible to the sense of touch, and extending as far as the artery can be traced. Atheroma is a focal or nodular thickening, due largely to calcarcous degeneration. Professor William Russell has introduend the term " hypertonus" to describe a vessel " the muscular" coat of which is unduly contracted, so that the watl is thicker and the lumen sinaller."

We obtained specimens of sercral radial arteries from men who met with fatal accidents during the course of our inquiry. Dr. L. R. Sutherland, professor of pathology. in University College, Dundee, very kindly examincd these for us. Excerpts from his reports are as follows.

Scction of Radiul from a Man agcd. 2\%.- "Localized thickenings of the intima are readily observed: in some sections as much as one-third of the lumen is involved. Some of the patches are six times as thick as the normal intima. The thickened tissue is tolerably cellular. There is no evidence of fatty degeneration or 
calcareous infiltration. The media underlying the larger thickerings is atrophied."

Sections from the oller arteries show similar changes varying only in degree. Photomicrographs of two sections are reproduced; the first (Fig. 1) shows a patch of thickening of medium size at the giving off of a small branch, and the other (Fig. 2) shows the cellular nature of the thickening.

These reports give a clear indication of the pathological conditions of the arteries in the cases we have examined. Tho thickening is shown to be in the intima, and does not

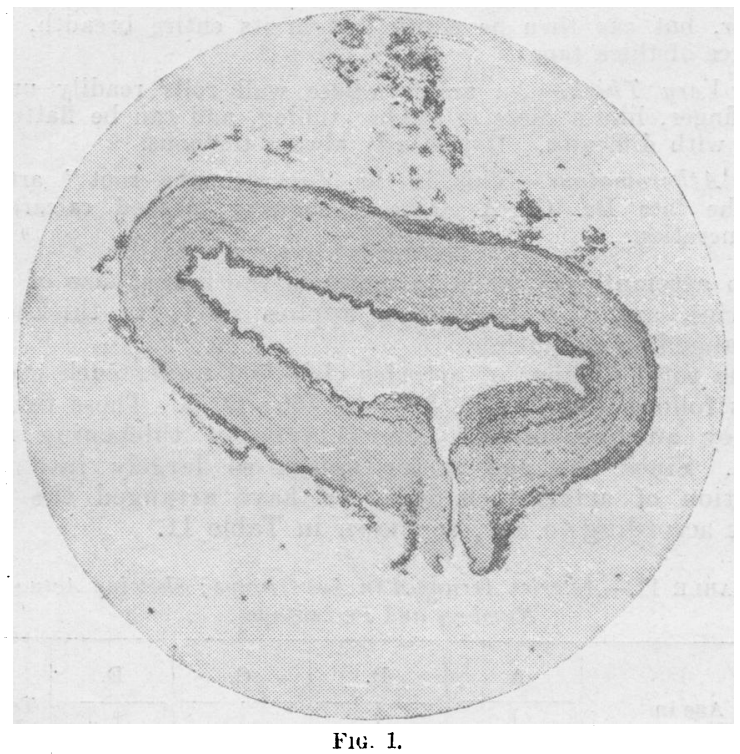

involve, in any of the sections examined, the whole circumfercnce of the vessel, and there is no evidence whatever of thickening of the muscular coat or adventitia.

So far as we can discover, arterial changes similar to those have never before been described.

\section{Blood Pressure.}

As blood pressure varies within certain not ret accurately defined limits, not only in different individuals, but to almost as great a degree in each individual under the influence of various conditions, there can be no fixed standard of normal blood pressure. But $60 \mathrm{nim}$. of mercury with the $12 \mathrm{~cm}$. armlet is accepted by most authorities as the lowest systolic pressure in adult males consistent with health; while $140 \mathrm{~mm}$. mav be taken as the greatest systolic pressure which should be regarded as normal, at least up to middle life. Of our cases 449 out of the 500 that is, 80 per cent.- had blood pressure falling within normal limits, and only 51 (10 per cent.) showed blood pressure over 140

The estimation of the diastolic pressure was discontinued after about two hundred readings were laken,"as it was apparently of little significance so far as the inquiry was concerned. It was practically always from 25 to $40 \mathrm{~mm}$. below the systolic pressure, as has been found by other observers. The blood pressures at different age groups are shown in Table III.

TABLE III.

\begin{tabular}{|c|c|c|c|c|c|c|c|c|}
\hline \multirow{2}{*}{\multicolumn{3}{|c|}{ Age Group. }} & \multicolumn{6}{|c|}{ Blood Pressures. } \\
\hline & & & $\begin{array}{l}100 \text { and } \\
\text { under. }\end{array}$ & $\begin{array}{l}100 \mathrm{tos} \\
110 .\end{array}$ & $\begin{array}{l}110 \text { to } \\
120 .\end{array}$ & $\begin{array}{l}120 \text { to } \\
130 .\end{array}$ & $\begin{array}{l}130 \text { to } \\
140 .\end{array}$ & $\begin{array}{c}\text { Over } \\
140 .\end{array}$ \\
\hline \multicolumn{3}{|c|}{20 years and under } & 10 & 23 & 42 & 26 & 8 & 2 \\
\hline $21-30 \ldots$ & ... & $\ldots$ & 3 & 21 & 64 & 53 & 26 & 17 \\
\hline $31-40 \ldots$ & $\ldots$ & $\ldots$ & 1 & 8 & 41 & 33 & 25 & 8 \\
\hline 41-50 $\ldots$ & $\ldots$ & $\ldots$ & 3 & 4 & 13 & 12 & 18 & 9 \\
\hline o:er 50 & $\ldots$ & ... & 0 & 1 & 6 & 4 & 4 & 15 \\
\hline Tota & $\ldots$ & $\ldots$ & 17 & 57 & 165 & 128 & 81 & 51 \\
\hline
\end{tabular}

Relation of Arterio-sclerosis to Blood Pressure.

There exists even now a general impression that arteriosclerosis is necessarily associated with increased blood pressure. Professor William Russell, for example, asserted that "thickened arteries never give normal readings." The result of this inquiry is entirely opposed to that view. Over and over again we met with cases where the arteries were very thick and the blood pressure was well below the normal maximum; while, on the other hand, perfectly soft-

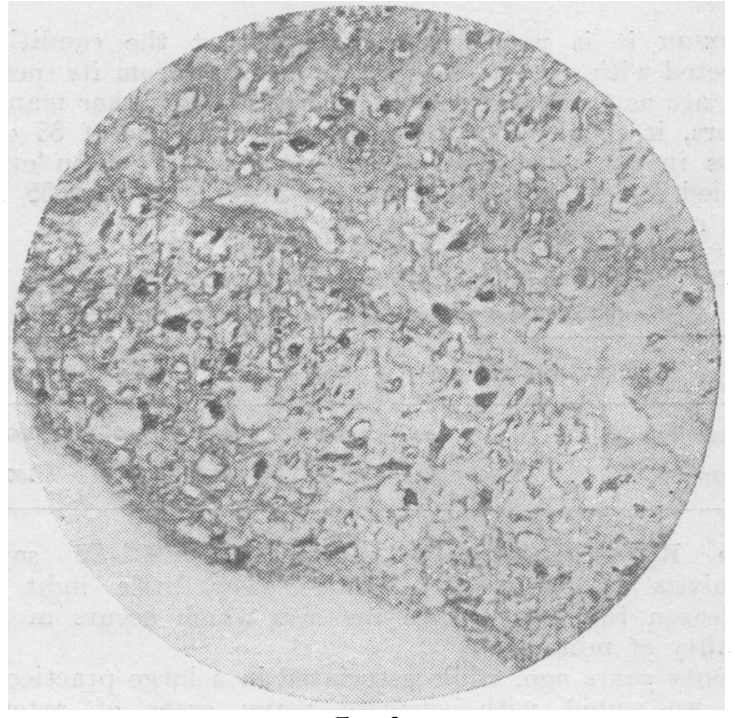

Fig. 2.

walled arteries were fomd in conjunction with high readings. We annex a number of cases showing great variations in blood pressime from arteries of the same apparent degree of thickening.

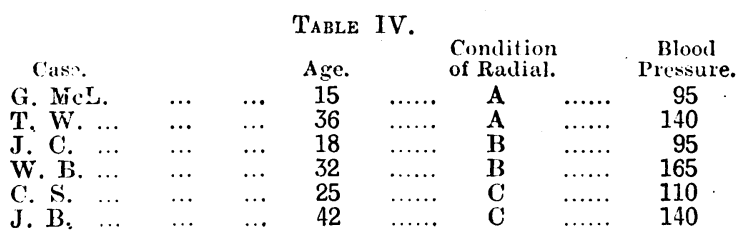

A table is also given of the actual numbers showing " normal" pressure in each artery group.

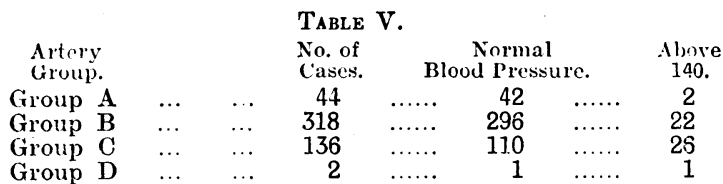

This seems to show that the recorded blood pressure has little relation to actual thickening of the artery wall, vitinin certain limits. (It should be mentioned that in any case where there was moluly high blood pressure the urine was examined for albumin, but with a negative result in every case.) Russell's assertion that "thickwalled" arteries never give normal readings" is clisposed of by such a case as the following.

S. S., aged 42 , had very thick and tortuous arterics, which could be traced from his wrist riglit up to his axilla, and felt betwech the finger and thumb to be round and hard like a lead pencil; his blood pressure was on several occasions 118 to 120 . A tracing of this case is given (Fig. 3), showing the first return of pulsation after obliteration of the ressel, and the abscissa, from which one can measure the absolute height of the blood pressure without the risk of error due to the personal equation. This tracing , was kindly made for us by the late Dr, G. A. Gibson, who confirmed our description of the arteries. The blood pressure was 118.

Many of our cases distinctly showed hypertonus; in fact, as tho great majority had normal blood pressure, it is safe to conclude that the others were examples of hypertonic contraction. This was evident during the course of the examinations, when occasionally pressures were recorded 
from men who had just had teeth extracted, whitlows opened, and the like, and almost without exception these were over 130.

C'lifford Allbutt described three raricties of arteriosclerosis: (1) hypertonic, with increased blood pressure;

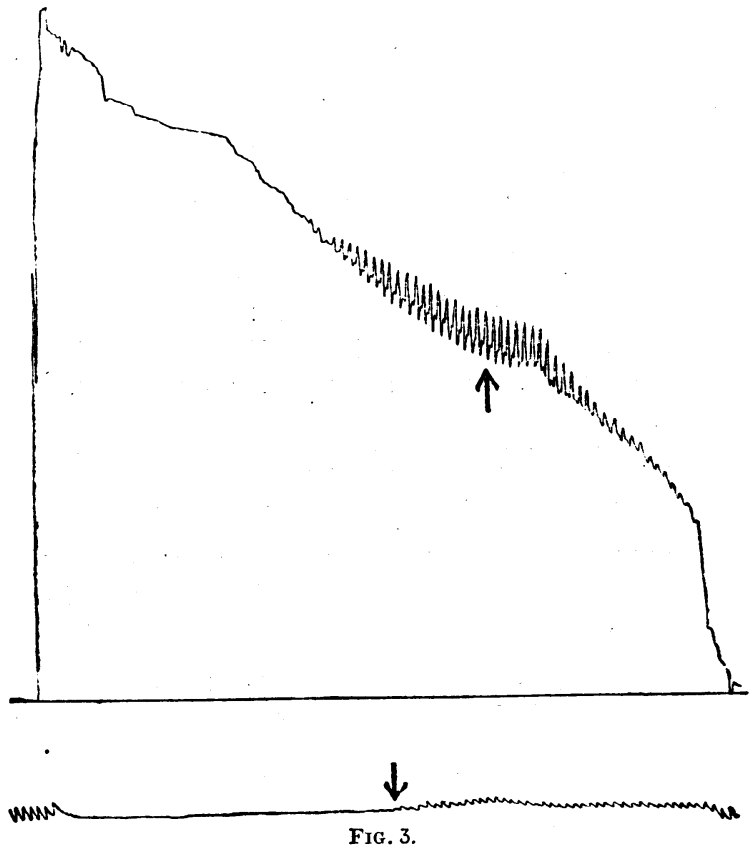

(2) toxic, in which there is usually no increase of blood pressure, and not infrequently a decrease; (3) decrescent, or senile. There is no doubt that most of our cases are examples of Clifford Allbutt s toxic group-that is to say, they have thickened arteries, with normal or low blood pressure.

Causes of Arterio-sclerosis.

The subject of the causation of arterio-sclerosis is as darkened by conflicting statements as is the pathology. Kidney disease, old age, high blood pressure, defective alimentation, chronic intoxications of all kinds, acute infections, muscular exertion, have all in turn been brought into the limelight. These seemingly widely divergent views as to the etiology may perhaps be reconciled by considering them all as variations of the one common factor-that is, a toxaemia.

In our cases the following points were investigated: (1) acute infections, including syphilis; (2) meat consuniption; (3) amount of tobacco used; (4) alcohol consumption; (5) conditions of work. The first four of these may be dismissed briefly, as they did not suggest any explanation of the prevalence of the thickened arteries. It is perhaps worth recording that only two patients gave a history of syphilis, and these were both ex-soldiers. (This was prewar.) Syphilis among miners is exceedingly rare.

The jesults of the inquiry as regards alcohol should also be recorded. The easiest and probably most nearly

Table VI.-Effect of Alcohol; showing Condition of Radials and Blood Pressure.

\begin{tabular}{|c|c|c|c|c|c|c|c|c|c|}
\hline \multirow{2}{*}{$\begin{array}{l}\text { Amount } \\
\text { spent on } \\
\text { Alcohol } \\
\text { Per Week. }\end{array}$} & \multirow{2}{*}{$\begin{array}{l}\text { No. of } \\
\text { Men. }\end{array}$} & \multicolumn{4}{|c|}{ Condition of Radials. } & \multicolumn{4}{|c|}{ Blood Pressures. } \\
\hline & & A. & B. & C. & D. & $\begin{array}{l}\text { Ep to } \\
100 .\end{array}$ & $\begin{array}{l}\text { Up to } \\
120 .\end{array}$ & $\begin{array}{l}\text { Un to } \\
140 .\end{array}$ & $\begin{array}{l}\text { Orer } \\
140 .\end{array}$ \\
\hline $\begin{array}{lll}\text { Nil } & \ldots & \\
& \ldots\end{array}$ & 183 & 20 & 146 & 17 & 0 & 14 & 95 & 63 & 11 \\
\hline 1s. $\ldots$ & 103 & 8 & 61 & 34 & 0 & 1 & 38 & 48 & 16 \\
\hline viv to 5 s. .. & 123 & 7 & 59 & 56 & 1 & 3 & 41 & 62 & 17 \\
\hline$\tau_{1}$, to $10 \mathrm{~s} . .$. & 38 & 6 & 21 & 11 & 0 & 0 & 19 & 14 & 5 \\
\hline$\tau_{1}$ to $£ 1 \ldots$ & 27 & 3 & 16 & 8 & 0 & 0 & 12 & 11 & 4 \\
\hline Orer $£ 1 \quad \ldots$ & 26 & 0 & 15 & 10 & 1 & 2 & 8 & 7 & 9 \\
\hline Totils ... & 500 & 44 & 318 & 136 & 2 & 20 & 213 & 205 & 62 \\
\hline
\end{tabular}

accurate method of estimating the amount of alcohol consumed by an individual in this walk of life is to ascertain how much he spends on alcoholic liquors per week. Our figures are as nearly right as any obtainable, for we know personally practically every man examined, and had a rery good idea of his tastes and opportunities.

This table, contrary to expectation, shows that there is no essential relation between the amount of alcohol taken and the degree of thickening of the arteries or the blood pressure. Similar tables could be given in connexion with meat and tobacco, again showing no relation between these ronditions. We therefore came to the definite conclusion that alcohol, meat, and tobacco have little or no effect in causing the changes in the circulatory system which we liave described.

The fifth point investigated, " conditions of work," presented the only factor common to all the cases, and special attention was naturally directed to these conditions.

When this inquiry was undertaken there was little ccalcutting machinery below ground; most of the hewing was done by hand, and at that time it was agreed by experts that the actual physical work required of coal miners was not in excess of that of any class of ordinary workmen-for example, joiners or bricklayers. Any difference in the mortality rates between miner's and other occupied males is certainly not due to any excessive muscular effort required by their work.

In the area under investigation the pits vary in depth from 600 to over 2,000 feet; they are ventilated generally on the vacuum system, by which means a current of ai: which may amount to 200,000 cubic feet per minute is distributed through the workings. Though this seems a large quantity, it must be remembered that there are over twenty miles of underground roads in a large pit. As the coal is worked out in any area of a pit, the strata left aro at first supported by timber pillars, so that these waste workings contain a vast quantity of decomposing wood. The practical importance of this will be noted later.

Since the miner works down the pit for eight hours each dar, it is obvious that the composition of the air which he is breathing for such a period is a matter of great importance. We therefore securcd analyses of simples of the air from various parts of one of the typical pits in the area. The two abnormal constituents which may be found in mine air are $\mathrm{CH}_{4}$ and $\mathbf{C O}$. $\mathrm{CH}_{4}$ (fire-damp as it is called) has no direct action on man, and acts simply as a diluent of the oxrgen. CO is only present in exceptional circumstancesfor example, when a sean of coal is burning, or after an cxplosion, either of fire-damp or in the process of coalgetting by explosives. The figures concerning these gases, as well as of the nitrogen present, are therefore left out of the analytical samples given in Table VII.

$$
\begin{aligned}
& \text { Table VII.-Analyscs of Air in Typical Pit (Pcrecntagcs). } \\
& \text { Place of Observation. } \\
& \text { 1. At surface } \\
& \text { 3. Intake air course } 1,000 \text { feet from } \begin{array}{llllll}
\cdots & \cdots & 0.05 & \cdots & 20.85
\end{array} \\
& \text { 3. Intake air course 1,000 feet from bottom } \begin{array}{llll}
0.15 & \ldots & 20.59
\end{array} \\
& \begin{array}{llllllll}
4 . \text { At a working face } \ldots & \ldots & \ldots & \ldots & 0.30 & \ldots & 19.84
\end{array}
\end{aligned}
$$

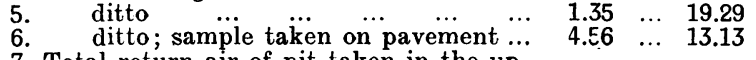

$$
\begin{aligned}
& \text { 7. Total return air of pit taken in the up- } \\
& \text { cast shaft in a current of } 200,000 \text { cubic } \\
& \begin{array}{llllllll}
\text { feet per minute } \ldots & \ldots & \ldots & \ldots & 0.22 & \ldots & 20.51
\end{array}
\end{aligned}
$$

We would draw special attention to the amount of $\mathrm{CO}$. present in different localities in the pit, and contrast it with the normal and "extraordinarily constant" amount in air above ground-that is, 0.03 per cent.

The figures given do not represent bad ventilation frol:t the mining standpoint. We have it on the authority of sereral general managers that air containing 0.7 per cent. of $\mathrm{C}^{\mathrm{O}}$ represents good ventilation, while working places showing 1.35 per cent. and the like are referred to by the miner himself as having "dull air," and it is notorious that men work in such atmospheres for prolonged periods without raising serious objections. In these atmospheics a lamp will buirn somewhat dimly, not owing to the actual quantity of $\mathrm{CO}_{2}$ present, but to the deficiency of oxygen; and a light (a tallow candle) only gradually goes out when the oxrgen is reduced to 17.6 per cent. Such atmospheres hare little or no appreciable effect on breathing, pulse rate, 
or blood pressure. We tested this on ourselves below ground in " dull air," and in one section which had been abandoned on account of bad ventilation. The differences noted were: slight slowing of the respiration (16 as compared with 18 above ground), and slight increase in pulse rate (84 and 72); it was not possible to take a blood pressure reading there as the light was so poor.

The large amount of $\mathrm{CO}_{2}$ in mine air requires some explanation. There is, of course, no consumption of $\mathrm{CO}_{2}$ underground; on the contrary, it is being produced constantly. The amount present is only to a very slight degree due to respiration of men and ponies and the burning of oil lamps. It is almost entirely due to the oxidization of wood and of the cxposed surfaces of the coal, together with the gas actually libesated from the (on! itself.

The other obvious abnormal factor in the conditions of work uncerground, in addition to the composition of the inspired air, is the absence of darlight. It is evident that in winter, at least, many miners seldom see sunlight or even davlight. The importance of this is only now being fully recognized, but at present we are not prepared to assess its signifieance in the subject under inguiry. We have, however, been able to trace a progressive thickening of the arteries with the length of time during which the men worked underground; this is shown in Table VIII.

TABIE VIII.

\begin{tabular}{|c|c|c|c|c|c|c|c|}
\hline \multirow{2}{*}{\multicolumn{4}{|c|}{$\begin{array}{l}\text { Duration of Wcrk } \\
\text { Underground. }\end{array}$}} & \multirow{3}{*}{$\begin{array}{c}\begin{array}{c}\text { No. of } \\
\text { Men. }\end{array} \\
44\end{array}$} & \multicolumn{3}{|c|}{ Condition of Arteries. } \\
\hline & & & & & \multirow{2}{*}{ A. } & \multirow{2}{*}{$\frac{B .}{23}$} & \multirow{2}{*}{ c. } \\
\hline (1) Under 1 year & $\ldots$ & $\ldots$ & $\ldots$ & & & & \\
\hline (2) $1-5$ years... & ... & $\cdots$ & & 111 & 6 & $90 \hat{~}$ & 9 \\
\hline (3) 5-10 years & $\ldots$ & $\ldots$ & .. & 108 & 7 & 79 & 22 \\
\hline (4) 10-20 years & $\ldots$ & $\ldots$ & .. & 112 & 6 & 69 & 37 \\
\hline (5) 20-30 years & $\cdots$ & $\cdots$ & .. & 71 & 4 & 38 & 29 \\
\hline (6) 30-40 years & $\ldots$ & $\ldots$ & ... & 39 & 0 & 10 & 29 \\
\hline (7) Over 40 years & $\ldots$ & $\ldots$ & $\therefore$ & 15 & 0 & 3 & 12 \\
\hline Total $\ldots$ & $\ldots$ & $\ldots$ & $\ldots$ & 500 & 44 & 318 & $1: 8$ \\
\hline
\end{tabular}

It is seen that of 44 men who had worked below ground one rear or less, no fewer than 21 had normal arteries-that is, 48 per cent.; and those wre not only boys, but included men up to 30 years of age: In no other grouping of the cases is it possible to get such a large percentage of normal arteries. It is also noticeable that there is a distinct inclease in the amount of thickening of the arteries with the curation of orcupation unclerground.

Wrom this last table it seems evident that work below ground, under the conditions of ventilation shown to prevail, has a definite relation to the prevalence of arteriosclerosis in coal miners. We believe that it is this arteriosclerosis, with its sulsequent results on general nutrition, which accounts for the increased mortality of coal miners after the age of 55. For although statistics may not show conclusively that miners suffer from diseases of the circuiatory system more than men in other occupations, yet it is only to be expected that such an insidions pathological condition as arterio-sclerosis will in many cases fail to be recognized as the initial cause of death.

It has been our experience to meet with many miners who, while not complaining specially of any circulatory disturbances, have the physical appearance, while still on the right side of 60 , of having summed up their threescore years and ten; and in many cases we have seen these men dying at or ahout the age of 60 with all the symptoms of vascular degeneration.

\section{Summary.}

1. There is an unexplained difference in the mortality rate of coal miners as compared with other oceupied males.

2. The results of the consecutive examination of the circulatory system of 500 coal niners are anaiysed.
3. It is shown that among coal miners of all ages there is an extraordinary prevalence of thickened arteries; the thickening is confined to the intima in the specimens examined.

4. There is no associated rise in blood pressure.

5. The only significant constant factors are $(a)$ the inhalation of air of altered composition, especially the $c O$, content; and $(b)$ the absence of daylight.

6 . It is suggested that the arterio-sclerosis shown to exist in coal miner's is the explanation of the peculiarity in their mortality rate.

\section{DIFEUSE PNEUNOCOCCAL PERITONITIS IN A BOY:}

Post-Operative Paralytic Ileus Theateo by Anti-GiasGaxarene Seruar : Empyemi: Recovery.

BY

B. SOUTAR SIMPSON, M.B., F.R.C.S.ED., SURGieon, LAWSON MEMORIAL hospital, GOlsPie, SUTHerLAND.

Sincr 1926, when Williams ${ }^{1}$ drew attention to the uses of anti-gas-gangrene serum in peritonitis and intestimal obstruction, many encouraging results have been described following the use of the serum in such cases. Molesworth ${ }^{2}$ rightly sounds a note of caution in accepting, such enthusiastic clinical reports of a comparatively new form of treatment. I venture to publish the following account of a case of diffuse pneumococcal peritonitis where antigas-gangrene serum had a beneficial effect and the patient recovered from a disease in which the mortality is adlnittedly very high.

A boy, aged 15 years, who had previously been in good health and had never suffered from any serious illness, was admitted to hospital on Mav 25th, 1929, with acute abdominal svmptoms. Ho had become suddenly ill five days previously with severe abdominal pain and romiting. There was no rigor. The pain was spasmodic, increased gradually in severity, and was felt most acutely in the lower abdomen, especially in the right sids. From the commencement of the attack the bowels were constipated. No frequency of micturition was noted, but the boy at times complained of pain during the act. At no time did the patient have any cough oi" chest symploms. (For the above particulars I am indebted to Dr. W. W. Tumer, Lochinver, who recommended the case.)

On admission the patient was in a critical condition. He was very thin, the face was pinched, the exprcssion anxious. The lips and finger-tips showed some cyanosis. The temperature was $102^{\circ} \mathrm{F}$., the pulse rate 126 , irregular and fechle; tho respirations were 24 per minute. The tongue was dry and furred, and the breath was foul. There was no herpes labialis. He complained of severe and continuous abdominal pain, mosi marked in the umbilical and right iliac regions. There was frequent romiting of offenvive brown watery matter, which was very acid in reaction. The abdomen was moderately distended, immoliile, and intensely rigid all over. Cutaneous hyperaesthesia and tenderness were most marked in the umbilical region and the right lower ciuarrant. The percussion note was tympanitic except in the flanks, where some dullness was present. There was no cough, and nothing abnormal could be detected on examination of the chest. The right tonsil was moderately enlarged and appeared to be slightly inflamed.

Opcrution.-As a preliminary morphine $1 / 6$ grain and alropine 1/100 grain were given. Anaesthesia was induced with gas and oxygen, and followed by open ether. The abdomen was opened by a right paramedian incision. Much thin yellowish pus at once escaped and was seen oozing from all directions. The pus had a peculiar musty odour, and contained small flakes of lymph. There were no signs of adhesions even in an early stage of formation, the infection being diffuse. The peritonitis was, however, distinctly more intense in the right infra-colic compar:ment. The caecum, appendix, and subperitoneal tissucs were oe:lematous and injected. The small gut was of a diall red colour, had lost its gloss, and appeared lifeless. The glands at the root of the mesentery were cnlarged and inflamed. The peritoneal cavity having been cleansed as much as possible, and the appendix removed, a drain was placed in the pouch of Douglas through a separate stab wound in the mid-line. Tho original wound was closed, with a small drain in the lower angle.

Pathological Beport.-The direct preparations showed many pus cells and numerous Gram-positive diplococci. Inoculated medis yiclded pure growths of a pneumococcus. 